\title{
Vegetation geographical patterns as a key to the past, with emphasis on the dry vegetation types of South Africa
}

\author{
M. J. A. WERGER*
}

ABSTRACT

Southern Africa is characterized by a highly diversified vegetational cover with extremes as contrasting as desert, tropical forest, alpine grassland, or mediterranean type scrub, and many other types in between. This vegetational pattern is strongly correlated to the climatological pattern. It is therefore likely that past changes in climate can still be partly traced in the vegetational pattern, particularly in geographical anomalies, and that study of these patterns provides complementary evidence to palynological research. The following anomalies in the vegetational pattern are briefly discussed:

1. island-wise occurrence of Afro-montane vegetation on mesic, sheltered sites in the southern SudanoZambezian Region, in particular in the Highveld grassland/False Karoo transition area;

2. similar westward occurrence of Sudano-Zambezian scrub patches in the Karoo-Namib Region near the Orange/Vaal confluence;

3. scattered occurrence of Sudano-Zambezian woody species in a matrix of Karoo-Namib vegetation in the marginal Karoo-Namib Region;

4. island-wise occurrence of frost-tolerant, dry, karroid dwarf shrub vegetation of predominantly $\mathrm{C}_{3}$-plants on isolated peaks in the winter rainfall area of Namaqualand;

5. peculiar patchy distribution of some succulents in wide areas of climatically rather homogeneous, succulent dwarf shrub vegetation of predominantly CAM-plants in the escarpment area of Namaqualand, a pattern reminiscent of that in many Cape fynbos species.

Interpretation of these patterns logically leads to the conclusion that these result from a previously wetter, a previously cooler, or a previously wetter and cooler climate. respectively, over the parts of southern Africa under discussion. This conclusion is compared with published palynological views.

\section{RÉSUME}

LE PASSÉ MIS EN LUMIERE PAR L'ANALYSE GÉOGRAPHIQUES DES ASPECTS DE LA VÉGETATION, EN S'APPUYANT SUR LES TYPES DE LA VÉGÉTATION SËCHE DE L'AFRIQUE DU SUD

L'Afrique de Sud est caractérisée par une couverture végétale très diversifiée avec des extrêmes aussi contrastés que le désen, la forêt tropicale, les formations herbeuses alpines ou les formations brouseilleuses de type méditerranéen et beucoup d'autres formations intermédiaires. Ce profil de la végétation est en étroite corrélation avec celui du climat. Il est par conséquent vraisemblable que les changements de climats du passé puissent encore être partiellement observés dans les aspects de la végétation, particulièrement dans les anomalies géographiques et que l'étude de ces aspects puisse fournir des arguments complémentaires à ceux de la recherche palynologique. Les anomalies suivantes des aspects de la végétation sont brièvement discutées:

I. Existence d'îlots de végétation a fromontagnarde dans des sites abrités et à humidité moyenne dans le sud de la Région soudano-zambézienne, en particulier dans la zone de transition de la formation herbeuse du Highveld et du Faux Karoo;

2. Existence vers l'ouest, de formation brouseilleuse soudano-zambézienne dans le Région du Karoo-Namib près ću confluent du Vaal avec l'Orange;

3. Existence à l'etat dispersé d'espèces ligneuses soudano-zambéziennes dans une trame de végétation Karoo-Namib, dans la Région du Karoo-Namib marginale;

4. Existence sous forme d'îlots d'une végétation arbustive naine, sèche, karroïde, résistant à la gelée et componée de plantes à prédominance $C_{3}$ sur les pics isolés dans la région à pluies hivernales du Namaqualand:

5. Une réparition particulière sous forme d'îlots de certaines succulentes dans de vastes régions à végétation arbustive naine crassulescente à climat plutôt homogène, composée de plantes à prédominance CAM dans la zone d'escarpements du Namaqualand, aspect rappelant celui de nombreuses espèces de fynbos du Cap.

L'interprétation de ces aspects conduit logiquement à la conclusion qu'ils résultent respectivement d'un climut antérieurement plus humide, antérieurement plus froid ou antérieurement plus humide et plus froid, qui a régné sur ces parties concernées de l' A frique du Sud. Cette conclusion est comparée avec les considérations palynologiques qui ont été publicés.

\section{INTRODUCTION}

In all of Subsaharan Africa, South Africa stands out due to its great diversity of vegetation types. Within relatively short distances, one finds such extremes as, for example, desert vegetation, tropical lowland and montane forest, savanna woodland,

- Botanische Oecologie, Lange Nieuwstraat 106, 3512 PN, Utrecht, Nederland. mediterranean type scrub and alpine grasslands, and several transitions between these types. The distributional pattern of these various vegetation types is strongly correlated with the climatological pattern.

On the south-western edge of the country, between the coast and the escarpment, which is up to about $2000 \mathrm{~m}$ high, there is a winter rainfall regime, eastwards passing into a uniform, all-year 
rainfall regime. This area is covered by the mediterranean type scrub and heathlands; only here and there we find forest-vegetation of Afromontane affinity in this area. Going northwards, the west coast and the western escarpment remain under the winter rainfall regime until well into South West Africa (Namibia), but total rainfall drops to just a few centimetres per year on average and its reliability strongly decreases, thus causing desert and semi-desert conditions.

South Africa's interior, the east coast and the northern part of the country, all fall entirely within the summer rainfall regime. Isohyets in this part of the country generally run north-south and there is an increase in average annual precipitation from about $200 \mathrm{~mm}$ at about $700 \mathrm{~km}$ away from the west coast to considerably over $1000 \mathrm{~mm}$ near the east coast. In parts of the eastern escarpment formed by the Drakensberg, the rainfall can reach $2000 \mathrm{~mm}$ per year (Schulze \& McGee, 1978; Killick, 19-8).

The vegetation accordingly shifts mainly in an eastern direction away from the west coast, from desert and semi-desert dwarf shrub vegetation to zonal grassland, montane grassland and scrub with locally montane forests to alpine vegetation on top of the escarpment, and again scrub and woodland vegetation lower down the escarpment towards the east coast, where occasionally some coastal forest is still found. Towards the northern parts of South Africa the effects of proper tropical conditions increase, and the vegetation becomes mainly a savanna woodland, forming the southern edge of the vast Sudano-Zambezian phytogeographical region (Werger \& Coetzee, 1978).

The broad correlation between climate and vegetation is clear from this general picture, but more detailed climatic factors can also be correlated with distribution of the vegetation. In the dry western part of South Africa, for example, the vegetation of the coastal belt and the escarpment zone is strongly succulent, except for the highest mountain reaches, where frosts of more than 4 or 5 degrees occur regularly. On these higher parts of the mountains the vegetation becomes dominated by sclerophyllous, small-leaved karroid dwarf shrubs. Beyond the escarpment zone on the interior plateau, in the area where the uniform, all-year rainfall regime passes into the summer rainfall regime, we again come into an area with regular frosts of similar severity and again see the vegetation change from a succulent dwarf shrub vegetation to a sclerophyllous, small-leaved dwarf shrub vegetation (compare Werger, 1978a). Much further eastwards, about half-way between the west and the east coast, in the Upper Orange River area, there is a climatic boundary approximately indicated by the $400 \mathrm{~mm}$ isohyet, which coincides remarkably well with the borderline between the true Karoo-Namib dwarf shrub communities, the Pentzietea incanae, and the more grassy, and in their affinity more SudanoZambezian, karroid communities, the PentzioChrysocomion and the Rhoetea erosae communities (cf. Werger, 1980).

Many more, and probably even more striking examples could be mentioned. Most of these examples will illustrate that, although there is a correlation between the distribution of the vegetation and of the various soil types, generally speaking the correlation between climate and vegetation is much more pronounced (see also Coetzee \& Werger, 1975).

The strong correlation between the distributional patterns of climate and vegetation suggests that past changes in climate, especially the most recent and significant ones, may have left their marks on the distributional pattern of the vegetation, and that it is likely that such climatic changes, in part can still be traced in the present vegetational pattern. These marks will be clearest in geographical anomalies in the distribution of plant species and vegetation types, which is not to say that each such anomaly must be interpreted in terms of past climatic changes.

I shall discuss a number of surprising, aberrant distributional patterns in vegetation types which, at first sight, are difficult to explain. They may be interpreted as possible traces of relatively recent climatic changes and the logical conclusions noted. The conclusions may be compared with those of the palynologists working in Southern Africa. As I am more familiar with the dry parts of South Africa, examples will chiefly be drawn from that area.

\section{ABERRANT DISTRIBUTIONAL PATTERNS}

1. In the eastern Orange Free State and Lesotho, shrubby communities of Afromontane affinity are very common on the stoney slopes of hills and mountains. In the Afromontane zone of Lesotho these communities may occur in continuous belts, but further westward their occurrence is patchy and is interrupted by the extensive grasslands of the Highveld. Still further westwards (around $26^{\circ} 30^{\prime}$ EL) the grasslands merge into the open dwarf shrub vegetation of the False Karoo which contains species of Karoo-Namib affinity. In this area, patches of scrub vegetation of Afromontane affinity are very rare and of very limited extension. They do occur, however, and are described from steep, sheltered and cool southern slopes in the Upper Orange River area, as Rhamno-Rhoetum scrubland by Werger (1980). They contain species like Myrsine africana, Rhamnus prinoides, Kiggelaria africana, Celtis africana, Grewia occidentalis, and many other shrubs, herbs and graminoids abundant in the higher, cooler and wetter parts of southern Africa. The patchy distribution pattern of this vegetation type fading out in a westward direction, the westwardly diminishing abundance and presence of Afromontane species in stands of this community, as well as the ecological characteristics of its habitat (see Werger, 1980), strongly suggest that the present occurrences are remnants from a previously more continuous westward extension of the distribution area of this vegetation type. Such an extension can only have existed under generally wetter and perhaps cooler conditions. Judged from the climatic conditions under which the Afromontane vegetation in the eastern Orange Free State and Lesotho optimally occurs, especially wetter conditions must 
have prevailed in order to allow a more continuous westward extension as required for this explanation.

2. The pattern described above is more or less repeated a few hundred kilometres further westward (between $23^{\circ} 30^{\prime}$ and $24^{\circ} \mathrm{EL}$ ), where well within the domain of the Pentzietea incanae communities which are strongly of Karoo-Namib affinity, stands with a clear Sudano-Zambezian affinity occur on sheltered, south-eastern slopes of dolerite. These stands belong to the Zizipho-Rhigozetum obovati association described by Werger (1980). SudanoZambezian species occurring in these stands include Themeda triandra, Digitaria eriantha, Heteropogon contortus, Sansevieria aethiopica and many others.

This isolated, patchy occurrence of SudanoZambezian vegetation islands on sheltered sites within the Karoo-Namib area again suggests a formerly more continuous westward extension of these vegetation types. This again asks for a formerly somewhat wetter climate in that area.

This westward 'penetration' of vegetation types of generally wetter and/or cooler areas into the drier and warmer areas is remarkably reminiscent of the 'distant satellite' distribution pattern of several Afromontane species westwards along watersheds, discussed by White $(1978,1981)$ as the Zambezi, Limpopo and Magaliesberg extensions.

3. The southern Kalahari represents a marginal savanna area on deep sandy soils. The affinity of its flora is mainly Karoo-Namib, and therefore the area is included within that phytogeographical region (cf. Werger, 1973, 1978a). However, Karoo-Namib species are nearly all species of the fieldlayer (which constitutes by far the most significant part of southern Kalahari vegetation), whereas especially in the very open layer of shrubs and small trees, a number of Sudano-Zambezian species are important. This Sudano-Zambezian group mainly concerns woody species with a relatively deep root system that enables them to draw on the water supplies deeper in the ground. As most of the Karoo-Namib species of the southern Kalahari do not possess such a relatively deep root system, they cannot draw on these moisture resources. This co-occurrence of ecologically and phytogeographically contrasting plant species within the same community, suggests that it is just a temporary stage resulting from a climatic shift: during a previously more humid period the Sudano-Zambezian vegetation types occupied an area which extended much further southwestward, including all or most of the southern Kalahari. With the more recent gradual climatic desiccation the shallow-rooting species of the field layer could not cope with the increasingly severe periodic droughts in the uppermost sandy soil layers and could not maintain themselves. They were replaced by Karoo-Namib species which stand prolonged periods of drought better. The deeperrooting shrubs and tall trees, however, did not meet this water problem to quite the same extent, since the deeper layers of the sandy soil as yet contain sufficient water under the present rainfall regime. Therefore, these Sudano-Zambezian species were able to maintain themselves in a progressively aridifying area.
Also the marginal woodland communities described from the vicinity of Mafeking by Van der Meulen (1979) and consisting of a similar mixture of species of Karoo-Namib and Sudano-Zambezian affinities, can perhaps best be interpreted in this way.

A similar explanation seems possible for the stands of the Sudano-Zambezian Colophospermum mopane, deeply penetrating the northern part of the Karoo-Namib region in South West Africa (Namibia) along dry valleys and islandwise tapering out in a westward direction (Werger \& Coetzee, 1978). In this case it is, of course, also possible that the distribution pattern results from regeneration from seeds brought by occasionally flowing rivers in these valleys, though Colophospermum cannot be regarded as a fluviatile species. Should this distributional pattern be interpreted as resulting from a previously wetter period, this period cannot be interpreted as having been much colder as well, since Colophospermum mopane is very sensitive to low temperatures, its southern boundary coinciding largely with the $5^{\circ} \mathrm{C}$ isotherm of mean daily minimum temperature for the coldest month (see Henning \& White, 1974).

4. The higher parts of the high mountains of the western escarpment in Namaqualand are islands of narrow-leaved sclerophyllous dwarf shrub vegetation in an area generally covered with strongly succulent dwarf shrub vegetation. In physiognomy and floristical composition, this sclerophyllous dwarf shrub vegetation is strongly related to the karroid vegetation of the interior plateau, which experiences summer rainfall and, in an eastward direction, increasingly severe and frequent frosts in the winter season, as well as an increasingly higher annual precipitation. The plants making up the karroid sclerophyllous vegetation on the Namaqualand mountain tops and on the interior plateau are predominantly of the $\mathrm{C}_{3}$-photosynthetic type, whereas the succulent dwarf shrub vegetation of Namaqualand is extremely rich in plants having the Crassulacean Acid Metabolism (CAM) for photosynthesis (Werger \& Ellis, 1981). Massive occurrence of CAM-plants seems to be limited by both a threshold of too low and one of too abundant moisture supply, while on the other hand the moisture supply must be rather regular. Namaqualand with its dry winter rainfall climate and its frequent nightly or early-morning fog and dew, seems to meet these requirements. On the other hand, regular frosts of a certain severity, the suggestion is a lower limit of about -4 or $-5^{\circ} \mathrm{C}$, seem to prevent the massive occurrence of CAM-plants. It is most likely that the regular occurrence of such low temperatures in the higher parts of the Namaqualand mountains is the main reason why the succulent dwarf shrub vegetation is replaced there by sclerophyllous dwarf shrub vegetation, which is frost-tolerant, even though the general moisture conditions on these higher parts are perhaps favourable for CAM-plants. On the other hand, the more frequently humid conditions in the higher parts of these mountains may also favour the narrow-leaved, sclerophyllous karroid dwarf shrub vegetation there. 
A second interesting feature of these sclerophyllous karroid vegetation islands, and one that contrasts strongly with the case to be discussed next, is that apparently there has been relatively little speciation within these islands; there are relatively few endems restricted to single or few mountain tops, and the species composition appears to be rather constant from island to island. In this respect this sclerophyllous dwarf shrub vegetation differs from the fynbos vegetation capping the mountain tops further southwards in the marginal area of the Karoo. In these isolated fynbos islands local endems apparently are more common (cf. Taylor, 1978).

The low-temperature tolerance of the sclerophyllous $\mathrm{C}_{3}$-dwarf shrubs, their possibly higher moisture demands, and the scarcity of extremely localized endems together point to a recently cooler and perhaps wetter climate in this area under which the sclerophyllous vegetation islands formed a continuous belt, and the succulent vegetation was restricted to considerably lower altitudes than at present.

These cooler and perhaps wetter conditions must have existed until rather recently, otherwise the sclerophyllous vegetation islands would most probably have shown a far higher degree of speciation through isolation.

5. In the same area of Namaqualand discussed above, but in the succulent dwarf shrub vegetation, a number of succulent species show a very remarkable distribution pattern. Though growth conditions for succulent dwarf shrub vegetation seem to be fairly constant over wide stretches of land at lower and middle altitudes, a surprisingly large number of species show a very patchy distribution: one species is restricted to a limited plain or slope, whereas on the adjacent plain or next slope another closelyrelated, but distinct species takes its place, and there are no identifiable differences in ecological conditions between these sites that would explain such a replacement of species. In fact, the distribution areas of these closely-related species often are not even interrupted by ecologically different sites but form one homogeneous habitat area. This patchy distribution is especially frequent within the Mesembryanthemaceae, though it seems not to be restricted to it; with closer study it probably will also be found in the Portulacaceae, Crassulaceae, Liliaceae and Euphorbiaceae. Several examples are now known from the mesembryanthemaceous genera Mitrophyllum, Psilocaulon, Aridaria, etc. and gradually more cases of this phenomenon come to light through the thorough investigations of prof. Ihlenfeldt and his co-workers into this family. Hartmann (1977), for example, reported a very similar distribution pattern for the species of the mesembryanthemaceous genus Argyroderma in the quartzitic Knersvlakte in southern Namaqualand. This type of patchy distribution resembles the pattern of highly localized endems in the area of the Cape fynbos vegetation. It is a kind of distribution that creates high $\gamma$-diversities in the sense of Whittaker (1977).

A plausible explanation for this patchy and localized distribution pattern of some closelyrelated, but distant species of succulents in an area that often appears as homogeneously 'suitable' for each of the species, is that it again results from a previously decidedly cooler and perhaps wetter climate. Under such a climate frosts will have been more severe and more frequent, and conditions will have been generally more humid, both favouring the sclerophyllous vegetation now concentrated on the higher parts. Such conditions diminished the habitat suitable for the succulent dwarf shrub vegetation to a few favourable sites, which, limited in size, protected them against the coldest temperatures by their exposition, their exposure to mild sea winds, and their low elevation. In these isolated favourable sites, selection pressures must have worked effectively on a rather small gene pool, with the result that in some cases distinct species evolved parapatrically in each or several of these islands. This process of speciation so far resembles the evolution by biotype depletion assumed by Wild (1965) for many endems of the serpentine soils of the Great Dyke in Zimbabwe (see also literature cited in Goldblatt, 1978: 410). Keeping in mind the ecophysiological requirements of the Namaqua succulents, the climate, though cooler, must have been a winter rainfall climate, with a regular, but not too high moisture supply [see above under (4)]. When the climate became warmer and drier, the area suitable for these succulents extended and the isolated patches expanded, enlarging into a continuous stretch of favourable land, only locally interrupted by unfavourable mountain tops. With the expansion of the suitable habitat, the distribution areas of the succulents increased and met each other.

In several cases, where small, isolated populations had not evolved into distinct species, the isolation was removed and an exchange of genetic material into one larger and genetically more diverse population must have resulted. Where distinct species had evolved, however, newly interconnected island-areas could either exchange their species or, when these species are ecologically similar, upon immigration, they could have outcompeted one another in some of the previously isolated areas. Of this latter phenomenon there is little evidence in Namaqualand, since in several cases closely-related but distinct species occur in 'pure areas' within short distances from one another, without much immigration or overlap of distribution areas being noticeable. Even when keeping in mind that antitelechoric devices are common in plants of arid regions, and thus also in the Namaqua flora (Stopp, 1958, Werger, 1978a), this apparent lack of mutual penetration into the distribution areas of the previously isolated species strongly suggests that the change from a cooler to a warmer climate must have occurred relatively recently.

\section{COMPARISON WITH OTHER PALAEOCLIMATIC FINDINGS}

The conclusions from the cases discussed above is that the aberrant distributional patterns in a considerable number of vegetation types point to a recently wetter and cooler climate over much of South Africa, and certainly in the central, western and southern parts. In at least the central parts it 
appears that the higher humidity was all-important, whereas on the western escarpment the lower temperatures possibly may have been of equal or more importance than the increased humidity.

Though the anomalies discussed here allow these conclusions, they cannot be dated so that they do not allow a clear conclusion on whether or not change in climate occurred everywhere at the same time, and to a very limited extent only on whether or not such a climatic change occurred once or repeatedly.

All palynologists agree that, since the Pleistocene, there have been repeated changes of climate that have been of different magnitude. Geomorphologists agree with this finding (e.g. Harper, 1969; Street \& Grove, 1976; Heine, 1978, 1979). Van Zinderen Bakker $(1975,1978)$ states that at present we are in the second half of an interglacial. During a glacial period the presently tropical parts north of South Africa received much less rainfall and were cooler than at present, wheras the latitudes at which South Africa is situated were wetter and cooler as the winter rainfall area extended further northward and further inland. Coetzee $(1978 \mathrm{a}, \mathrm{b})$ describes these changes in temperature, precipitation and seasonality as a result of pendulating shifts in climatic regimes during the Quaternary, and gives evidence from various disciplines. Though results also definitely point to a previously cooler and wetter climate, evidence has not been found of a predominantly winter rainfall regime during that period. But, except for the more westward extension of the Sudano-Zambezian element into the dry areas, no evidence was found to the contrary either. The limited evidence available from pollen data from South Africa indicates that there was a definite change in climate from rather dry and warm to more humid and cool around 25000 B.P., whereas other pollen diagrams have shown repeated alternations from wet-cool to dry-warm conditions between about 13000 and 10000 B.P. (Van Zinderen Bakker, 1978; Coetzee, 1967, 1978a, b). Geomorphological evidence (Heine, 1978, 1979, 1981) showed that in the southern Kalahari the time-span from 18000 to 13000 B.P. was cool and sometimes wet, sometimes dry with spatially strongly different conditions. Around 30000 B.P. it probably was wet, and the data indicate that this wet period probably lasted till at least 25000 B.P. As the southern Kalahari often fell in the transition area of the winter and summer rainfall regimes during the Quaternary, the data are difficult to interpret. More recent alternations of such climatically contrasting spells have been reported (e.g. Frenzel in Van Zinderen Bakker, 1969; Street \& Grove, 1976; Heine, 1981). It is, therefore, likely that the patterns discussed here result from different periods of wet and cooler climate, especially since, for example, case (3) probably indicates a less drastic climatic change than that required to result in the pattern of cases (4) and (5). The palynological and geomorphological evidence suggests, however, that the patterns discussed here are of a more recent origin than the arid disjunctions across Africa reported extensively elsewhere (see e.g. Werger, 1978a). It should be stressed that the most important result from the investigation presented here, is that the conclusions independently arrived at by a logical analysis of present vegetation geographical anomalies are not at variance with the palaeoclimatic findings of palynologists and geomorphologists, but seem to confirm them.

\section{REFERENCES}

Coetzee, B. J. \& Werger, M. J. A., 1975. A west-east vegetation transect through Africa south of the tropic of Capricorn. Bothalia 11: 539-560.

CoetzeE. J. A., 1967. Pollen analytical studies in East and Southern Africa. Palaeoecology of Africa 3: 1-146.

CoetzeE. J. A., 1978a. Late Cainozoic palaeoenvironments of southern Africa. In E. M. van Zinderen Bakker Sr., Antarctic glacial history and would palaeoenvironments 115-127. Rotterdam: Balkema.

Coetzee, J. A., 1978b. Climatic and biological changes in south-western Africa during the Late Cainozoic. Palaeoecology of Africa 10/11: 13-29.

Goldblatt. P., 1978. An analysis of the flora of southern Africa: its characteristics, relationships, and origins. Ann. Mo. bot Gdn 65: 369-436

HARPER. G.. 1969. Periglacial evidence in southern Africa during the Pleistocene epoch. Palaeoecology of Africa 4: 71-101.

Hartmann. H., 1977. Monographie der Gattung Argyroderma N. E. Br. (Mesembryanthemaceae Fenzl). Mitt. Inst. allg. Bot.; Hamb. 15: 121-235.

HEINE, K., 1978. Jungquartäre Pluviale und Interpluviale in der Kalahari (südliches Afrika). Palaeoecology of Africa 10/11: $31-39$

Heine. K., 1979. Reply to Cooke. Catena 6: 259-266.

HeINE. K., 1981. Aride und pluviale Bedingungen während der letzten Kaltzeit in der Südwest-Kalahari (südliches Afrika) Z. Geomorph. N. F. Suppl. Bd. 38: 1-37.

Henning, A. C. \& White. R. E., 1974. A study of the growth and distribution of Colophospermum mopane (Kirk ex. Benth.) Kirk ex J. Leon: the inter-action of nitrogen, phosphorus and soil moisture stress. Proc. Grassld Soc. sth. Afr. 9: $53-60$.

KILliCK. D. J. B., 1978. The Afro-alpine Region. In M. J. A Werger, Biogeography and ecology of southern Africa 515-560. The Hague: Junk.

Schulze. R. E. \& McGeE. O. S. 1978. Climatic indices and classifications in relation to the biogeography of southern Africa. In M. J. A. Werger. Biogeography and ecology of southern Africa 19-52. The Hague: Junk

STOPP. K., 1958. Die verbreitungshemmenden Einrichtungen in der südafrikanischen Flora. Bot. Stud. 8: 1-103.

Street. F. A. \& Grove. A. T. 1976. Environmental and climatic implications of late Quaternary lake-level fluctuations in Africa. Nature 261: 385-390.

TAYLOR. H. C., 1978. Capensis. In M. J. A. Werger. Biogeography and ecology of southern Africa 171-229. The Hague: Junk.

VAN DER MEULEN. F., 1979. Plant sociology of the western Transvaal bushveld, South Africa. Diss. Bot. 49. Vaduz Cramer.

Van Zinderen Bakker. E. M. . Sr. (Ed.). 1969. Palaeoecology of Africa. 4. Cape Town: Balkema.

VAN ZiNDEREN Bakker. E. M. Sr, 1975. The origin and palaeoenvironment of the Namib Desert biome. $J$. Biogeogr. 2: 65-73.

VAN ZiNderen BaKkeR. E. M. Sr, 1978. Quaternary vegetation changes in southern Africa. In M. J. A. Werger, Biogeography and ecology of southern Africa 131-143. The Hague: Junk.

WERGER. M. J. A., 1973. Notes on the phytogeographical affinities of the southern Kalahari. Bothalia 11: 177-180.

Werger. M. J. A., 1978a. The Karoo-Namib Region. In M. J. A. Werger, Biogeography and ecology of southern Africa 231-299. The Hague: Junk.

WERGER. M. J. A., (Ed.) 1978b. Biogeography and ecology of southern Africa. 2 vols. The Hague: Junk.

WERGER. M. J. A., 1980. A phytosociological study of the Upper Orange River Valley. Mem. bot. Surv. S. Afr. 46: 1-98. 
Werger. M. J. A. \& Coetzee, B. J., 1978. The SudanoZambezian Region. In M. J. A. Werger, Biogeography and ecology of southern Africa 301-462. The Hague: Junk.

Werger. M. J. A. \& ElLis, R. P., 1981. Photosynthetic pathways in the arid regions of South Africa. Flora 171: 64-75.

WHITE, F., 1978. The Afromontane Region. In M. J. A. Werger, Biogeography and ecology of southern Africa 463-513. The Hague: Junk.
WHITE. F., 1981. The history of the Afromontane archipelago and the scientific need for its conservation. Afr. J. Ecol. 19: 33-54.

WhITTAKER, R. H., 1977. Evolution of species diversity in land communities. Evol. Biol. 10: 1-67.

WILD, H., 1965. The flora of the Great Dyke of southern Rhodesia with special reference to the serpentine soils. Kirkia 5: 49-86. 